\title{
Small Literature as a Problem. Could It Be Solved?
}

\author{
DALIA SATKAUSKYTE்
}

\begin{abstract}
The article discusses the status and functioning of so-called small literatures, including Lithuanian literature, in the global system of world literature. Referring to Franco Moretti and Pascale Casanova's interpretation of world literature system as based on the principle of inequality, the author discusses the conception of belonging to small literatures as a destiny and interprets the onecentric world literary system as hegemonic. Being dominated by grand literatures, small literatures have very restricted possibilities of gravitation towards the center of world literature. In that theoretical context, the article considers the following issues: is it possible and how is it possible to avoid the destiny of small literatures staying in the periphery of world literature, what role in this situation plays the writer himself, what depends on the culture and research politics, could literary scholars play the role of mediators and what could be the alternatives for onecentered world literary system.
\end{abstract}

Keywords: world literature; Franco Moretti; Pascale Casanova; small literature; planetarity

\section{Introductory Remarks}

\section{An Optimistic Project of World Literature and Implied Inequality}

In the year 1827 in a conversation with John Peter Eckermann, Johann Wolfgang von Goethe raised the idea of world literature:

I am more and more convinced that poetry is the universal possession of mankind, revealing itself everywhere and at all times in hundreds and hundreds of men... I therefore like to look about me in foreign nations, and advise everyone to do the same. National literature is now a rather unmeaning term; the epoch of world literature is at hand, and everyone must strive to hasten its approach. (Goethe 1984: 132)

Since world literature as a universal literary space has been reconfigured many times and in many different ways, it facilitated a reconsideration of the notion 'comparative literature' and the practice of comparing literatures. For example, the classics of modern literary theory, Rene Wellek and Austin Warren, criticize 
the term comparative literature itself, pointing out that it does not indicate either any specific subject of literary research (it is still about national literatures), or method ("comparison is a method used by all criticism and sciences, and does not, in any way, adequately describe the specific procedures of literary study", Wellek, Warren 1949: 38). "Comparison between literatures, if isolated from the concern of total national literatures, tend to restrict themselves to the external problems of sources and influence, reputation and fame", - summarize Wellek and Warren (Wellek \& Warren 1949: 40). They prefer the project of world literature or general literature, which implies a universal history of literature, since most of the problems of literary research are on an international, rather than national level ("The history of themes and forms, devices and genres, is obviously an international history”, ibid. 42). However, they admit that since world literature covers an enormous geographical area, there are structural differences, centers and peripheries, and this structure depends on the spread of the language used (in Europe, literatures written in German, Romanic and Slavic languages are considered central). Although the authors of Theory of Literature do not consider the issue of small literatures, it is easy to see that they are given a place in the periphery of world literature, and that in Goethe's imagined universal concert of literatures small literatures would certainly not be the main performers. In this book the idea of literary inequality is implicit, obscured by the model of horizontal relations (center-periphery). Sociologists and historians of literature as well as theoreticians of translation studies started openly discussing literary inequality in the late $20^{\text {th }}$ - early $21^{\text {st }}$ century and are considering it in a wider context of sociocultural, geopolitical and economic processes. However, for the most part, the problem of inequality is considered from the positions of the center or lost dominance (as in the case of French literature), and the voice of small literatures in this theoretical concert is hardly heard. However, lately it is getting louder.

The purpose of this article is to discuss the problem of a small literature as a participant of the global field of literatures. To discuss how it is seen from the outside - the center of the global model, and from within - from its own position; the aim is to reveal how they experience the structural constraints of global literature and the inequalities created by them. 


\section{A Look from the Outside: the Obvious Inequalities and the Fate of Small Literatures}

In the late $20^{\text {th }}$ - early $21^{\text {st }}$ century, the idea of inequality among the world literatures evolved from implicit to explicit. Probably its most straightforward formulation was presented by Franco Moretti in the manifesto "Conjunctures on World Literature" published in the year 2000. Refering to Karl Marx's theory of unequal economic exchange and Immanuel Wallerstein's typology of worldsystems, he asserts:

One, and unequal: one literature (Weltliteratur, singular, as in Goethe and Marx), or perhaps, better, one world literary system (of inter-related literatures); but a system which is different from what Goethe and Marx had hoped for, because it's profoundly unequal [...]. This is what one and unequal means: the destiny of a culture (usually a culture of the periphery, as Montserrat Iglesias Santos has specified [Morreti refers to Roberto Schwarz's article, 'The Importing of the Novel to Brazil and its Contradictions in the Work of Roberto Alencar', D. S.] is intersected and altered by another culture (from the core) that 'completely ignores it'. (Moretti 2000: 56)

Motivated by the prevalence of language, the Wellek and Warren's structural model of the center-periphery at least theoretically anticipates the dynamics of this structure ${ }^{1}$. According to Moretti, being a part of the periphery is an irrevocable cultural destiny that manifests itself as systemic single-sidedness (the grand literatures form the major global trends and assign smaller ones to the periphery of the system) and the asymmetry of knowledge circulation (small literatures constantly absorb or import the genre models, motifs, and techniques of the major literatures, while having no effect on them) ${ }^{2}$.

A similar view of small literatures is expressed in The World Republic of Letters by Pascale Casanova, which first appeared in French just slightly before the Moretti Manifesto ${ }^{3}$. Casanova also describes the place of small literatures in

1 On the dynamics of center-periphery, see Yuri Lotman's article "The Dynamic Model of a Semiotic System" (Lotman 1977: 193-210).

2 In later studies Morreti used qualitative comparative methods to try and identify the principles of hierarchy-building in the system of world literature (according to the domination, establishment, prevalence of motifs, etc. of a genre). See Moretti 1998; Moretti 2007.

3 La république mondiale des lettres by Casanova was published in 1999. Casanova developed Bourdieu's theory of the literary field, which was created based on national literature and applied it to world literature. In 2004 the book was translated into English, so it started to impact the research of world literature slightly later than Moretti. 
the field of world literatures as a result of the historical conditions that shape the cultural capital of these literatures. "The smallness, poverty, backwardness, and remoteness of these [italic, D. S.] literary worlds render the writers who live in them invisible-imperceptible in the strict sense - to international literary authorities" (2004: 182). One of the factors that determines this fate is the late appearance of these so-called small literatures, and that they usually emerged along with national movements (in the late $19^{\text {th }}$ century in Eastern and Central Europe). It is an inevitable and in a sense a positive process: "[p]oliticization in national or nationalist form - and therefore, in a sense, nationalization is one of the constitutive features of small literatures: proof, as it were, of the necessary link between literature and nation at the moment when a country takes its first steps toward revolt and dissimilation" (ibid. 189). Along with the emergence of nation states, autonomous literary fields also emerge, and in them antinational and anational writers can also finally appear.

This creates preconditions for some writers of small literatures to become visible in the republic of world literatures dominated by the international and universal dimensions. Casanova provides some rather radical examples that show how the representatives of small literatures become visible in the republic of world literatures. They are the Irish Samuel Beckett and James Joyce, who chose to write in greater languages, the Czech Milan Kundera (he writes in both his native Czech and French) or the Serbian Danilo Kiš, who has emigrated to Paris from communist-controlled lands, and so on. Emigration, hybridity and even assimilation are all fairly common trajectories of anational writers. Moretti uses similar terms to describe the possibilities of transnationality of literatures. His deliberations imply that any text that wants to have an "international career" must experience the state of exile. "Transplanted from their national soil, and forced to encounter extreme cultural and linguistic difference, literary forms jump the line into morphological innovation" is how Emily Apter presents the views of Moretti in Against World Literature, a book that revises the optimism of the project of world literature (Apter 2013: 58).

Naturally these are not the only opportunities. In the shift from national literature to world literature, translation as well as cultural policy play an important role as the main cultural mediators, but that is a separate, well-researched topic. The translation research only confirms the inequality of the global system of literature. Gisèle Sapiro summarizes it as follows: the flows of translation circulates mainly from the center toward periphery; the more dominant a culture, the more it exports and the less it imports (translated books represent only three percent of books published in the United States, the rate is even lower for literature (2011: 233). 
The success of a writer from a small literature has little effect on the structure of world literature and the place of small literatures in it, and the movement towards the polarity of universality does not free the writer from the attraction of nationality. Casanova has recorded the situation of an "international" small literature writer quite accurately:

But paradoxically it is the most international writers who, while rejecting adherence to national belief, are the best at describing the literary manifestations of national feeling. Critically, and with a certain vindictiveness, they express a complex truth to which they alone, by virtue of their position both inside and outside national literary space, are capable of bearing witness. The mixture of irony, hatred, compassion, empathy, and reflectiveness that defines both their ambiguous relationship to their country and their fellow countrymen, on the one hand, and, on the other, the rejection of all national pity - a rejection whose very violence is commensurate with the futility of their revolt - perfectly captures the literary sensibility of national belief in small countries. The inevitable perception of a cultural hierarchy in the world, and the need to defend and illustrate the claims of small countries, are signs of the tragic impasse in which national writers find themselves caught up as a result of this inexorable attachment to their nation. (2004: 186)

Casanova supports her claim by a quote from the Polish writer Witold Gomrowicz that reveals his ambivalent approach to Polishness. She also supports the inability of small literature authors to completely liberate themselves from national affiliations with the opinion of the Lithuanian writer Saulius Tomas Kodrotas: "I do not believe that one can escape one's origins. I am obviously not a patriot; I do not care about the fate of the Lithuanians... and yet I cannot stand completely outside, I cannot escape the fact of being Lithuanian. I speak Lithuanian; I also believe that I think Lithuanian."4 (Ibid. 181)

Public statements are not the only examples of Kondrotas's ambivalent national feelings, his prose is as well. Kondrotas never wrote on specific Lithuanian themes, his novels and short stories of magical realism are clearly oriented towards the universal dimension described by Casanova. For example, his

4 Saulius Kondrotas, Le Monde - Carrefour des littératures européennes, november 1992, interview to N. Zand. [Casanova's note.] Saulius Tomas Kondrotas (b. 1953) is a Lithuanian writer, who in 1986, when Lithuania was still in the Soviet Union, during a tourist trip asked for political asylum in Germany. He is probably the most translated author of Lithuanian prose. In emigration he tried to write in English but did not achieve success. He briefly returned to writing in Lithuanian but has basically abandoned his career as a writer. He currently lives in the USA where he works as a photographer. 
controversial short story "The Slow Birth of a Nation" ("Tautos gimimas") 5 can be interpreted as a very abstract narration of a community becoming a nation without any reference to Lithuanian history, but at the same time it could be interpreted as the national allegory, a form of narration, which, according to Fredric Jameson, prevails in the literatures of politically dominated countries (1986: 69) $)^{6}$.

Of course, this has not been an extensive review of the studies of the principle of inequality and its functioning in the field of world literature, however, providing a detailed review is not the purpose of this article. My aim is to draw attention to the position that researchers of world literatures take and to ask how this position affects the model of world literature itself.

Both Moretti and Casanova obviously take a position of the representatives of grand literatures who see certain dynamics in the hierarchy of world literature only for the literatures at its top. This is especially evident in Casanova's book, where from time to time the Franco-centric attitude is visible, along with bitterness due to the loss of the position Paris held approximately from the 16th century to around the $1960 \mathrm{~s}^{7}$. From the center, small literatures look like actors that lack independence, are late, trapped, thinking backwards, lacking sufficient political and cultural capital, and therefore are poor, and so on. Clearly, such a colonial view of small literatures is part of the formal model of world literatures which according to the reviewer of The World Republic of Letters completely ignores the esthetic evaluation of literature - artistic value is therefore not considered as a factor for global recognition (Austenfeld 2006: 142-143). Literatures that are distant from this 'Greenwich Meridian' (located between Paris, New York, and London) are considered as the others, inadequate, especially because of the domination of their national dimensions.

A decade later, Casanova slightly changed her attitude towards the national dimension of literature and the structure of the global literary field. As the editor of the book Des littératures combatives. L'internationale des nationalismes littéraires (Combative Literatures. International of Literary Nationalisms, 2011), she admits that the national dimension, especially in the case of small literatures, remains very powerful and still functions as the form of resistance against the inequality in the international literary field. She also reinterprets the notion of inequality

English translation of Kondrotas's short story see Kondrotas 2004.

6 For more details about Kondrotas's story as a national allegory see Cidzikaite 2006: 291-307.

7 According to the reviewer of Casanova's book, Thomas Austenfeld, "[h]er bold claim, in other words, is to declare Paris "the Greenwich meridian" of literary recognition" (Austenfeld 2006: 141-142). 
itself ("Needless to say, inequality between literatures is the structural and not the evaluative phenomenon") (2011:25).

The sign of the shift in the evaluation of literary nationalism is the fact that the volume under Casanova's edition also includes the French translation of Fredric Jameson's article “Third-World Literature in the Era of Multinational Capitalism” (Jameson 1986) where he focuses on the national dimension of the so-called third-world literatures, sometimes, as a Marxist, straightforwardly replacing the model of national literature with the class model. However, it is important that Jameson refers to a cultural reason for miscommunication, which also concerns the small literatures in general, including the post-Soviet ones. Jameson highlights the separation between the Western world literatures which are based on the differentiation of private, public, and political dimensions, and the third-world literatures which maintain these dimensions in close relation:

Third-world texts, even those which are seemingly private and invested with a properly libidinal dynamic - necessarily project a political dimension in the form of national allegory: the story of the private individual destiny is always an allegory of the embattled situation of the public third-world culture and society. (Jameson 1986: 69)

According to Jameson, it is because of this distinction, and the habit of Westerners to read foreign literature as their own, that third-world literature is so confusing for them (as confusing as it is for the younger generation of post-Soviet countries to understand literature written in Aesopian language). Such expropriation or complete rejection of literature that is different is "at one and the same time perfectly natural, perfectly comprehensible, and terribly parochial” (1986: 66).

\section{The alternatives to inequality, or how to escape the trap}

From the inside of the so-called small literature, especially one that's visibility in the field of world literatures was limited not only by being minor itself ${ }^{8}$, but also geopolitical circumstances (e.g. the Soviet occupation, as in the case of the

8 The sizes of populations or the amounts of published books are not the most important factor in defining a small literature. It is not so much a quantitative (though the volume of the readers and writers of one or another language is important), but more of a qualitative entity; it is defined by the many historical, cultural and political factors, among which it is important to emphasize the late appearance of the written word and formation of a partly autonomous field of literature, or simply Literature in a contemporary, Western sense. 
Baltic States), the inequality of the field or the system is not only obvious - we experience it every day in our academic activities, and quite paradoxically we even interiorize it in our research of our national literature.

Literary researchers are faced with inequality, such as the one described by Moretti or Casanova, at nearly every step as they try to move beyond the boundaries of national literature or the national academic field. Which one of us has not been confronted with such issues in preparing a paper for an international conference - when the short paper has to contain both the research problem and the short history of our national literature, as a context necessary for the scholarly community to understand our research idea? Who have not had the experience of how some of the literary scholars from the centers of world literature at those same conferences are not really listening to the papers on small literatures; simply because, as Moretti stated, "they totally ignore it"? Or listen only if one uses a bait, such as a comparison with some of the grand literary figures. For the agents of grand literatures, as well as literary critics, small literatures are often interesting only if they are a reflection of their own literature or are of exotic interest. The latest international successes of Lithuanian literature could serve as a proof of that - for Germans Antanas Škema is the Lithuanian Camus ${ }^{9}$, and for the French Ričardas Gavelis is the Lithuanian Kafka or Joyce ${ }^{10}$. Evidently, in presenting the translations of small literature authors it is not necessary to compare them

9 This is how Antanas Škema is presented by the German publisher Guggolz, which published the German translation of Antanas Škema's (1910-1961) novel The White Shroud (Das weiße Leintuch, first published in Lithuanian 1958, German translation 2017, trans. Claudia Sinnig). The novel achieved great success in Germany, the reviews were published in the biggest German newspapers. Although written from the perspective of a Lithuanian expatriate, this novel completely corresponds to the type of transnational work described by Morrreti and Casanova in its form (a modernist story of several layers), problematics (a person's existential situation after World War II), as well as its intertext (one of the most important ones - Albert Camus, The Myth of Sisyphus). It also contains the problematic connection to national affiliation described by Casanova. In 2018 an English translation of this novel was released (publisher Vagabond Voices, trans. Karla Gruodis).

10 Ričardas Gavelis (1950-2002), whose most well-known novel Vilnius Poker (1989), which also displays ambivalent feelings towards Lithuanian identity and its Sovietized version (homo lituanicus), is translated into several languages, including translation into English (trans. Elisabeth Novickas, 2009) and French (trans. Margarita Le Borgne, 2015). Although published by a small publisher, in France Gavelis's novel received considerable attention. The comparisons of his novel with canonical works of world literature can be found at the publisher's website http://www.monsieurtoussaintlouverture.net/ Livres/Gavelis/Vilnius_Poker_index.html. For more information about the French reception of Gavelis's novel see Bikulčius 2016. 
with the authors of the target language - usually some canonical works of world literature are enough. That becomes a necessary initiation into world literature without which it would simply be not possible to recognize the authors of small literatures. This strategy is not necessarily used with small literatures, and it is not necessarily discriminatory - it is also used when introducing the new authors of the so-called central literatures into the literary field, or simply to designate a place in the literary tradition. Comparison is an important methodological tool, and without it, as Wellek and Warren had noted, research not only in humanities would be difficult. However, I am deliberately escalating the situation because when it comes to writers of small literatures, comparisons with the grand literatures or the world literary canon often act as rejection or assimilation, described precisely by David Damrosch:

World literature has oscillated between extremes of assimilation and discontinuity: either the earlier and distant works reflect a consciousness just like ours, or they are unutterably alien, curiosities whose foreignness finally tells us nothing and can only reinforce our sense of separate identity. (Damrosh 2003: 133)

An example of the second strategy Damrosch identified could be Emmanuelle Tricoire's review of the anthology of Lithuanian prose published in French as Des âmes dans le brouillard (Mačianskaite 2003). The reviewer only appreciates what corresponds to the Western understanding of modernism, and what does not correspond to it (mostly the reviewer is disturbed by the excessive descriptions of scenery in Lithuanian prose, the tendency to express a person's feelings by transferring them to the scenery or natural phenomena, the passivity of the subject) is evaluated as cultural backwardness - in Lithuanian prose a person does not reach the status of the subject (he or she is neither a subject nor an object), he or she is hiding from the world (which is not completely inaccurate because this is a notion about prose written in the Soviet times), Lithuanian writers lack the vocabulary for feelings and so on. The reviewer finds a lot of similarities between the short stories of Lithuanian writers and the short stories of South Korea, and this comparison openly exoticizes Lithuanian literature and shows it as unutterably alien (Tricoire 2004).

The fate of a small literature to forever stay in the periphery manifests not only as external pressure, for example, writing in a way that makes it interesting for a foreign reader, adapting to the range of his knowledge (this may simply be a way to ensure normal communication or the need to speak about one's own literature in a broader cultural context). The hierarchical position of a small literature may be invisibly or visibly interiorized, as, for example, even in the title 
of my own article, "Why Škema Is Not Camus, or Some Thoughts on Lithuanian Existentialism" and the article itself, published in Lithuanian and intended for the Lithuanian reader (Satkauskyte 2012). Actually, as I was writing this article, I had no idea of confirming or somehow consolidating the hierarchic model of world literature; although today I see that I am myself using the strategy of assimilation identified by Damrosh. In the article I am discussing a certain change in hierarchy - the moment when Lithuanian literature, which is always behind the West (yet another confirmation of the fate of a small literature, according to Casanova), begins to speak of the world in "in its own time", so it starts playing "its part in a universal concert". Deconstructing myself in this way, I raise the question of whether the fate of a small literature to forever remain in the periphery, be little known, inaccessible and unread in the world is completely unchangeable. Is there any way out of this partly imposed and partly interiorized trap - to be always late, unknown, to be the different one, the other?

Western theoreticians have also raised this question on various occasions. For example, Jameson and Gayatri Chakravorty Spivak, who view the model of world literature from both the positions of the center and the periphery, and David Damrosh are suggesting a change of the point of view. They suggest that grand literatures should open up towards other literatures and abandon their habits of appropriation and exoticization that dominate cultural communication between grand and small literatures. "But why should we have to choose between a selfcentered construction of the world and a radically decentered one? Instead, we need more of an elliptical approach, to use the image of the geometric figure that is two foci at once" - thus Damrosh, referring not only to the geographical but also cultural differences (2003: 133). Spivak's book with a provocative title Death of Discipline (2003) suggests solving this problem with measures that complement each other. The first one is crossing borders - a method of linking the traditional comparative literature (whose death is discussed in the book) with social analysis, or area studies. This would allow a Westerner to at least catch a glimpse of and understand the literature of the other world, most of which remains outside the model of world literature. The second one is to create collectivities as a counter-position of hegemonic literatures ("To supplement Comparative Literature with (comparative) Area Studies allows us to rethink mere national-origin collectivities”, Spivak 2003: 53). The third one is to exchange the hegemonic concept of globalization for a planetary ${ }^{11}$ concept. Therefore, Spivak suggests the decentering of the model of world literature that is centered on grand literatures:

11 It is claimed that this concept of planetarity appeared in the literary and cultural critique earlier than Spivak coined it. According to Jeanette McVicker, one of the first 
As I hope above, the new Comparative Literature will touch the older minorities: African, Asian, Hispanic. It will take in its sweep the new postcoloniality of the post-Soviet sector [italics D. S.] and the special place of Islam in today's breaking world. Not everything for everyone, all at once. But a Comparative Literature format - historical and linguistic - possible, for any slice chosen from any of these places, the background filled in by new reference tools on Franco Moretti's model. (Spivak 2003: 84)

Recently, the multi-centered model proposed by Spivak seems to have started replacing the single-centered world literature model that emerged a couple of decades ago, and we already start talking about the Planetarity turn (Elias and Moraru 2015). At present it is more common to interpret the inequality-based single-centered world literature model not as one pre-determined by geopolitics, but as constructed and therefore deconstructable.

In her book Against World Literature, On the Politics of Untranslatibility. Emily Apter also asks a number of questions concerning the global model of world literature, which means nothing but the geopolitical recognition of superpowers and confirmation of their power. Is the Greenwich Meridian, described by Casanova, the only point of reference for creating a model of global literature? Or maybe we should admit that such a model is a hegemonic construction and the single-center needs to be replaced by a multitude of centers? Is the chronology of European literature translatable and is it necessary to translate it? Is it at all possible to transfer a theoretical model, created on the basis of one literature, to another that operates under different socio-cultural and geopolitical conditions? These are just some of the questions that Apter poses and that are more and more frequently asked by current researchers of world literature. Often, in raising these questions attention is drawn to the literatures of the non-Western, "third world" states (although this definition has also been criticized recently), the specifics of which are hardly important to the creators of a single-center world literature. They usually come into focus as examples of gravitating towards the center (language change, migration, assimilation). That is understandable - in such cases the clash of two different cultural paradigms is more radical and visible. However, it is somewhat different for the literatures of Eastern and Central European states, especially those that were occupied by the Soviet Union (among the discussed literary scholars only Spivak once referred to the post-Soviet sector). We are actually stuck in some sort of a grey area - neither are we Western enough, nor sufficiently exotic, and so often we and our literatures simply remain unnoticed.

scholars to use this term was a theoretician of postmodernism Ihab Hassan in his later works (McVicker 2016). 
So how can we leave this grey area, escape the dead-end prescribed for small literatures?

One option would be for us to abandon the single-centered, hierarchical model of world literature, to stop seeing ourselves as an inevitable part of the periphery of the global system of literature. It would be worthy to treat own literature as a part of world literature, assuming that instead of the hierarchic relationship between separate literatures there exists a parallel relation, that of diverse development. For Lithuanian literature is this option proposed by the Lithuanian scholar Aistė Kučinskienè in her article "The (Im)possibilty of Comparative Literature: Juozas Tumas-Vaižgantas and Miguel de Unamuno” (Kučinskienè 2017). A similar approach is taken by the researchers of Romanian literature in the book Romanian Literature as World Literature (Martin, Moraru, Terian 2018). They suggest reading a national literature as a world and in the world as existing "in a certain way that render literatures such as Romanian entirely or in some of their authors of works - no less "wordly", of the world, than presumably "major" literatures such as the French or British" (Martin, Moraru, Terian 2018: xiv). It is suggested that we interpret Romanian literature not as one affected by various influences, but as acting in the system of world literature, not as a hierarchically lower actor in the literary field, but as a crossroads in which various trajectories of world literature cross paths. It is hard to say whether such a strategy can help a small literature to be more visible among the grand ones, to be heard and not treated as exotic or as the imperfect Western other. But what it can really help with is coping with the feeling of inferiority, enacted by the concept of small literature as a fate.

In lieu of a conclusion: other strategies for acting in world literature

In lieu of a conclusion I would like to suggest a somewhat provocative list of both serious and ironic suggestions for small literatures -the possible strategies for acting in the field of world literature.

1. Be native informants for the creators of the global literary models (although Spivak criticizes this option for consolidating the existing situation). At least maybe there would be less nonsense spread around the world about small literatures.

2. Persistently talk about our own literatures on the international arena, even if we are not always heard. We can at least expect that someday someone will hear us. 
3. Do not give in to the hegemony of the grand literatures in the international literary space, and if necessary, tenaciously defend our positions.

4. Actively cooperate with the creators of the national cultural policy in creating strategies and tactics for popularizing national literature around the world.

5. Urgently appropriate the popular forms of prose and create a masterpiece in the field (according to Apter, a novel is a privileged genre in the market of world literature, Apter 2013: 67).

6. Create a unique, original literary phenomenon, which could affect even the literary centers (as was the case with the Latin American magic realism).

7. Think about what could replace the exploitation of the traumas of Soviet times in literature. Because it obviously gives away our ambiguous position it makes us more visible but at the same time defines us as inferior Westerners.

8. To do nothing in the hope that the situation will be conducive to the current condition of our literature (it is possible - even now it is said that in the West poetry is coming back into fashion and the ecological identity is expressed in long descriptions of scenery).

9. To find or create an "advocate" of small literatures, which would understand the grey zone of world literature. This should be a person of a similar caliber to Jameson or Spivak (although it is hard to imagine a literary theorist who would protect the rights of subaltern literatures in a Lithuanian or Estonian national dress, as Spivak did in a sari).

10. To push someone into the canon of world literature, as was successfully done by other small literatures (for example, the Swedish August Strindberg or Norwegian Knut Hamsun and Henrik Ibsen).

11. Use writers of Lithuanian origin who write in English (such as Antanas Šileika) and writers in emigration (such as Dalia Staponkute), in other words, to develop a third, transnational literary space.

12. And of course use Spivak's advice - create the collectivities of small literatures.

This list is a bit reminiscent of Jorge Louis Borges's animal classification. In my opinion, the creators of the literatures of the Baltic states should consider how to present both this region and their separate literatures as world literature, as well as a distinctive planetarity agent, and a crossroads of world literatures that creates a unique configuration.

\author{
Dalia Satkauskytė \\ satkauskyte@gmail.com \\ Antakalnio 6 \\ Vilnius LT-10308 \\ LIETUVA / LITHUANIA
}


SATKAUSKYTE்

\section{References}

Apter, E. 2013. Against World Literature. On the Politics of Untranslatibility. London, New York: Verso.

Austenfeld, T. 2006. Reviewed Work: The World Republic of Letters by Pascale Casanova, M. B. DeBevoise. - South Atlantic Review, 71 (1, Winter), 141-144.

Bikulčius, V. 2016. “Vilniaus pokeris” Prancūzijos kritikų akimis. - http://literaturairmenas.lt/literatura/vytautas-bikulcius-vilniaus-pokeris-prancuzijos-kritiku-akimis (16.04.2019).

Casanova, P. 2004. The World Republic of Letters. Trans. M. B. DeBevoise. Cambridge: Harvard University Press.

Casanova, P. 2011. La guerre de l'ancienneté. - P. Casanova, dir., Des littératures combatives. L'internationale des nationalismes littéraires. Paris: Raisons d'Agir, 9-3.

Damrosch, D. 2003. What Is World Literature? Princeton: Princeton University Press.

Elias, A. J., Moraru, Ch., eds. 2015. The Planetary Turn: Relationality and Geoaesthetics in the Twenty-First Century. Evanston, IL: Northwestern University Press.

Goethe, J. W. von. 1984. Conversations with Eckermann (1823-1832). Trans. J. Oxenford. San Francisco: North Point.

Jameson, F. 1986. Third-World Literature in the Era of Multinational Capitalism. - Social Text, 15, 65-88. https://doi.org/10.2307/466493

Kondrotas, S. T. 2004. The Slow Birth of a Nation. - Lituanus, 50 (3), 12-22.

Kučinskienè, A. 2017. Komparatyvistikos (ne)imanomybè: Juozas Tumas-Vaižgantas ir Miguelis de Unamuno. - Colloquia, 38, 51-70, http://www.llti.lt/failai/Colloquia38_ internetui-51-70.pdf.

Lotman, Y. 1977. The Dynamic Model of a Semiotic System. - Semiotica, 21: 3/4, 193 210. https://doi.org/10.1515/semi.1977.21.3-4.193

Mačianskaitè, L. 2003. Des âmes dans le brouillard. Anthologie de nouvelles lituaniennes contemporaines. Textes choisis et présentés par Loreta Mačianskaitė. Caen: Press Universitaire de Caen.

Martin, M., Moraru, Ch., Terian, A., eds. 2018. Romanian Literature as World Literature. New York: Bloomsbury.

McVicker, J. 2016. Thinking With the Planet: a Review of the Planetary Turn: Relationality and Geoaesthetics in the Twenty-First Century. - Electronic Book Review, 11.06, http://electronicbookreview.com/essay/thinking-with-the-planet-a-reviewof-the-planetary-turn-relationality-and-geoaesthetics-in-the-twenty-first-century/ (08.04.2019).

Moretti, F. 1998. Atlas of the European Novel, 1800-1900. London, New York: Verso.

Moretti, F. 2000. Conjectures on World Literature. - New Left Review, 1, JanuaryFebruary, 54-68.

Moretti, F. 2005. Graphs, Maps, Trees: Abstract Models for a Literary History. London, New York: Verso.

Sapiro, G. 2011. Comparativism, Transfers, Entangled History: Sociological Perspectives on Literature. - A. Behdad, D. Thomas, eds., A Companion to Comparative Literature. 
Small Literature as a Problem. Could It Be Solved?

Hoboken: Wiley-Blackwell, 225-236. https://doi.org/10.1002/9781444342789. ch15

Satkauskytè, D. 2012. Kodèl Škèma - ne Camus, arba šis bei tas apie lietuviškąjš egzistencializmą. - L. Mačianskaitè, ed., Antanas Škèma ir slinktys lietuvių literatūroje. Vilnius: Lietuvių literatūros ir tautosakos institutas, 39-51.

Tricoire, E. 2004. Timides présences. Le monde selon une littérature européenne. - https:// www.espacestemps.net/articles/timides-presences-le-monde-selon-une-litteratureeuropeenne/ (17.04.2019).

Wellek, R., Warren, A. 1949. Theory of Literature. New York: Harcourt, Brace \& Co. 